ANALELE ŞTIINTiIFICE ALE UNIVERSITĂȚII „ALEXANDRU IOAN CUZA” DIN IAŞI Tomul LII/LIII

\title{
THE NEW SERVICE ECONOMY AND IT'S IMPLICATIONS FOR STATISTICS
}

\author{
LAURA ASANDULUI
}

\section{Noua Economie a serviciilor şi implicațiile sale pentru statistică}

\begin{abstract}
The New Service Economy is an increasingly global economy in which businesses compete and communicate in a worldwide marketplace. High-technology and information-based goods and services are dominating today's economy. New business models are applied, and international business is changing profoundly. The New Service Economy poses opportunities as well as threats to data collection. In some instances, the existing data systems must be improved. The greatest challenge will be to devise new data systems designed to go beyond monitoring and with an explicit orientation to shed light on the underlying dynamics of the economy.
\end{abstract}

Key words: new service economy, services, statistical data, data systems, data collection

\section{Introduction}

The New Service Economy is an increasingly global economy in which businesses compete and communicate in a worldwide marketplace [NorthStar Economics.Inc]. Three forces drive the New Service Economy: knowledge, change and globalization. The global economy is becoming more tightly integrated. The last two decades have brought important advances in information and communications technologies enabling new and more efficient 'global' modes of business operation [Smith, Philip, 2003, 77]. High-technology and information-based goods and services are dominating today's economies, an increasing value being placed on knowledge and information. The widespread applications of information technology and the Internet are changing the very nature of production, distribution and servicing of goods and services. That's why the ability to effectively organize and communicate that knowledge and information is of great importance to the success of a New Economy business [NorthStar Economics.Inc].

\section{The New Service Economy}

The New Service Economy is characterized by: an information technology service sector organized in network forms of organization, an inflation rate below its fundamentals, a stock market boom, high rates of economic growth. Productivity gains are no longer realized within but between service firms, as the increase in variety raises added-value per employee. Whilst service innovators, such as the information technology manufacturers, get ever more productive, individual service firms will exhibit low productivity. Variety in the service sector enables service providers to lucrate rents, where fluctuations of these rents are

* Conferențiar doctor, Catedra de Statistică, Prognoză, Economie Agro-alimentară, Facultatea de Economie şi Administrarea Afacerilor, Universitatea „Alexandru Ioan Cuza”, e-mail: $\underline{\text { asand@uaic.ro }}$ 
the basis of more than proportional changes in the firms stock market value [Zagler, Martin, $2002,338]$.

Nevertheless, at the core of most discussions is the relationship between investment in and use of information technology, and faster productivity growth. There is a very important relationship between technology, productivity, and services: first, research shows that the use of information technology raises productivity and growth; second, information technology has raised the international tradability of services.

Industrial production techniques have been applied to service production without considering the difference between the production-oriented industrial economy and the service economy. Knowledge and digital technologies are an essential part of industrial manufacturing as much as they are of an Internet-driven economy. The use of knowledge in the digital economy, however, focuses on providing customers with more choices. Instead of standardizing products, the digital revolution drives firms to focus on maximizing value by customizing products and meeting consumption needs.

Typical information goods such as news and databases are subject to the same economics as industrial goods as long as they are traded as manufactured goods. Limitations of the industrial age will translate into the Internet economy even when newspapers and magazines are put on the Web if these online products are nothing more than digitized versions of their physical counterparts.

The global prevalence of the Internet has brought integration and versatility to the existing computer and network technologies, and has opened up possibilities for widespread applications of these technologies to conduct commerce, to provide entertainment and communication, to file and pay taxes, to manage personal finances, to conduct research and education, etc. In essence, the Internet fits its characterization as "the information infrastructure" necessary to carry out all types of market processes and transactions. The number of tasks based upon network computing is growing rapidly - e.g. teleconference, remote services, online transactions, chat lines, Internet broadcasting, electronic - commerce and so on. Even driving an automobile involves the Internet as it downloads maps and addresses from a satellite. The economic significance of the Internet and its associated technologies is their ability to affect a wide range of human activities, integrating existing practices and enabling new business and market processes.

\section{Sectoral contributions}

Services are very heterogeneous set of activities containing at the same time some of the most and perhaps least dynamic activities. Among the most dynamic sectors may be included those driven by new technology such as telecommunications and IT services [Cave, Bill, Varjonen, Seppo, 2004, 257].

The field of services became larger, and its dimensions are permanently changing both as a consequence of growing of services demand, and on behalf of changes in material production, as well as on behalf of the material changes of production. The development of services, the emergence of new categories, as well as the varying development paces of constitutive activities have entailed the emergence of new approaches. The tri-sector theory (according to which national economy divides into three sectors) which lie at the basis of the national statistics systems implies a restrictive approach which no longer reflects the current economic reality. This approach has its disadvantages in what concerns the collection and processing of statistic data at the national level concerning services in comparison with industry and agriculture.

In this context, some authors' opinion is that the field of services is more comprehensive than tertiary sector, thus, from the latter a number of special services were 
detached that were distinctly constituted in the quaternary sector. In an initial stage, progress-carrying sectors (such as research and education) were included, then information technology was added. Others authors also include health, culture, entertainment under the name of "people's care" sector [Ioncica, Maria, 1999, 42].

Deeper integration of the New Services Economy into economies around the world can raise productivity and GDP growth there. There is a lot of upward potential for growth in Europe from increased intensiveness in the use of information technology, particularly in services. Also, increased intensity in the use of information technology associated with the Service Economy can lead to more widespread international trade in services [Mann, Catherine, 2004, 5]. Manufacturing competitiveness is enhanced by intensive use of knowledge-based services. Highly developed countries include 'service economies'.

Statistical data clearly point out the increasing importance of services in the national economies, irrespective of their level of development. This is proved, among other elements, by the increase of the contribution of this sector to the creation of the GDP. In most national economies, services represent the sector with a major weight within the present macroeconomic structures. On one hand, the expansion of services has reached the proportion of a structural mutation that characterizes all national economies. On the other hand, the intensity of this phenomenon presents variations in connection with the level of development of each country's national economy [Ghibuțiu, Agnes, 2000, 91].

\begin{tabular}{|c|c|c|c|}
\hline Country & $\begin{array}{c}\text { Agriculture, sylviculture, } \\
\text { hunting, fishing }\end{array}$ & $\begin{array}{c}\text { Industry, } \\
\text { construction included }\end{array}$ & Services \\
\hline Austria & 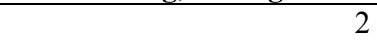 & 32 & 66 \\
\hline Belgium & 1 & 27 & 72 \\
\hline Bulgaria & 13 & 28 & 59 \\
\hline Croatia & 8 & 30 & 62 \\
\hline Czech Republic & 4 & 40 & 57 \\
\hline Denmark & 3 & 27 & 71 \\
\hline Estonia & 5 & 30 & 65 \\
\hline Finland & 3 & 33 & 64 \\
\hline France & 3 & 25 & 72 \\
\hline Germany & 1 & 30 & 69 \\
\hline Greece & 7 & 22 & 70 \\
\hline Hungary & 4 & 31 & 65 \\
\hline Italy & 3 & 29 & 69 \\
\hline Latvia & 5 & 25 & 71 \\
\hline Lithuania & 7 & 31 & 62 \\
\hline Luxembourg $^{1}$ & 1 & 20 & 79 \\
\hline Netherlands & 3 & 26 & 71 \\
\hline Norway & 2 & 38 & 60 \\
\hline Poland & 3 & 30 & 66 \\
\hline Romania $^{2}$ & 12 & 42 & 46 \\
\hline Slovakia & 4 & 29 & 67 \\
\hline Sweden & 2 & 28 & 70 \\
\hline Switzerland & 1 & 27 & 72 \\
\hline Turkey & 13 & 27 & 60 \\
\hline United Kingdom & 1 & 26 & 73 \\
\hline
\end{tabular}

Source: Anuarul Statistic al României 2004, 2005, 790 
For example, in 2000, Luxembourg (79\%) had a very high percentage of contribution of services to gross domestic product. In the year 2003, in certain highly developed countries the service industry contributed by more than $70 \%$ to the GDP: $72 \%$ in Belgium, $71 \%$ in Denmark and Netherlands, $72 \%$ in France, $73 \%$ in United Kingdom (table 1).

It is noticeable that in certain ex-socialist countries, the service industry similarly contribute to a large extent to the GDP: $65 \%$ in Estonia and in Hungary, $71 \%$ in Latvia, 67 $\%$ in Slovakia. The services sector in many developing countries, among which Romania, has tended to remain less developed. In Romania, the contribution of services to gross domestic product has a very low level $(47,4 \%$, in 2000 , and $46 \%$, in 2003$)$.

\section{Implications for Statistics}

Within the past two decades, several important drawbacks have been identified concerning statistical data in relation to services; these drawbacks have a negative impact on the relevance of the analyses in this area. The measure in which services are involved in all compartments of economic and social life emphasizes the extent of the activities in this sector, also its heterogeneity which makes it difficult to assess its true dimensions. Thus, the clear delimitation of the sphere of services has become a crucial issue.

The definition of services given by The World Bank excludes constructions and public services (electricity, utilities). In the classification system used by The World Bank, services represent a residual category consisting of the added value in the other sectors (retail and wholesale, banking and insurance services, transportation and communication, state administration and personal services). This leads to a process of undervaluation of the contribution of services to the GDP [Ghibutiu, Agnes, 2000, 101].

The methodology used by the national institutes/offices for statistics are not adequate, therefore some concepts must be redefined (the definition of the region NUTS II is a good illustration of this situation), statistical systems and classifications must be restructured. There is a need for improved harmonization of classification systems, concepts and statistical methods around the world.

The growth of trade in services, both inter- and intra-enterprise, has been greatly facilitated by the Internet and other new technologies, and these ,invisible' flows are far harder to measure than goods trade [Smith, Philip, 2003, 78].

The demand for information on the Service Economy is huge. This involves information on the way business is organised, on new economic activities, on the international dimension of the Service Economy, and on structural changes. It is also affected the ability of the statistical offices to supply it.

The Service Economy poses opportunities as well as threats to data collection. On the one hand, electronic ways of data collection are becoming increasingly common, and the level of detail of the available information is often immense. Administrative data sources tend to become increasingly accessible for statistical agencies. On the other hand, data collection is very difficult if business structures change rapidly or if businesses are spread over several countries. Also, the use of electronic data from businesses or from administrative sources requires an effort to establish the corresponding statistical unit(s) and translate the administrative concepts into statistical ones, including classifications [Strujis, Peter, 2002, 2].

As a consequence of the Service Economy, new business models are applied, and international business is changing profoundly. The Internet plays an increasing role in the communication businesses - consumers, and businesses - businesses. There are „virtual” businesses, and the organisation of distribution is changing in a profound way. The present 
statistical unit types, used in the European system of business statistics don't accomodate the new ways in which business is conducted?" [Strujis, Peter, 2002, 1].

The statistical units and classification categories must be sufficiently stable, but in some areas the volatility of the economic structure is extremely high. Thus, the existing data systems, in some instances, must be improved, and new types of statistical systems that are needed to inform public policy in key fields must be developed. The adaptability of the statistical system is very important. Also, the greatest challenge will be to devise new data systems designed to go beyond monitoring and with an explicit orientation to shed light on the underlying dynamics of the economy.

The development of new data systems should start with an attempt to understand the key outcomes that policies in a given domain would like to promote. There is a common interest that the goals of the government be carried out on the basis of the best available information, and that the same information be made equally available to others. A source of major difficulty is that in many areas, particularly in the social one, there are no broadly accepted outcome indicators.

An important step in developing useful data systems is high quality and operationally measurable outcome indicators. They are fundamental to monitoring progress toward objectives, telling us whether any improvement can be detected. On the one hand, a conceptual framework should guide the evolution of those data systems which quantify the interactions displayed by the framework. On the other hand, data systems should have a profound influence on the evolving conceptual framework: they should lead to the elimination of insignificant or irrelavant relationships and to the further elaboration of those that are most important [Fellegi, Ivan, 1999, 118].

\section{Conclusions}

The Service Economy means statisticians face considerable challenges in the future. Service industries are becoming an increasingly important part of modern economies. There is a corresponding interest in statistics about service industries. The challenges in compiling statistics are often very different to other industries.

Deficiencies in defining concepts, the sphere, classification systems, data collection methodologies, the degree of detail in presenting statistical data, international data comparability are issues facing international bodies with abilities in the domain of statistics, such bodies striving at present to improve their activity.

Great care will be needed to ensure the harmonisation of national data collection systems, according to international directives, so that comparable data series are provided to EU policy decision-makers and to other users like IMF, OECD, Worl Bank, etc.

\section{References}

Cave, B., Varjonen, S., International services statistics strategy and coordinationproblems and progress with price and volume measurement in the service setor, Statistical Journal of the United Nations ECE 21, IOS Press, 2004.

Fellegi, I., Statistical Services - Preparing for the Future, Survey Methodology, vol 25, no 2, 1999.

Ghibuțiu, A., Serviciile şi dezvoltarea, Editura Expert, Bucureşti, 2000.

Ioncică, M., Economia serviciilor, Editura Uranus, București, 1999.

Mann, C., The US Account, New Economy Services, and Implications for Sustainability, Review of International Economics, 2004. 
Smith, P., An overview of the CES seminar on 'Globalization and its impact on the world statistical system', Statistical Journal of the United Nations ECE 20, IOS Press, 2003.

Strujis, P., Defining Industries in the New Economy, IAOS Conference, London, 27-29 August 2002.

Zagler, M., Services, Innovation, and the New Economy, in Structural Change and Economic Dynamics, vol. 13(3), Wien, 2002.

http://www.northstareconomics.com/the new economy.htm, accesat pe 5 iunie 2005 Anuarul Statistic al României 2004, INS, Bucureşti, 2005. 